\title{
Discurso fundador: análise semiótica de textos das Sagradas Escrituras
}

\author{
Sueli Maria Ramos da Silva* \\ UFMS \\ Recebido em: 30/06/2019 \\ Aceito em: 20/12/2019
}

\begin{abstract}
Resumo: Retomando a perspectiva greimasiana de estudos bíblicos, nosso trabalho tem como objetivo específico depreender mecanismos de construção do sentido de alguns excertos do Antigo e do Novo Testamento, tidos como cenas fundadoras dos enunciados de divulgação e de fidelização religiosa. A partir da observação das recorrências dos mecanismos de construção do sentido dos enunciados reunidos por meio deste artigo, procuramos estabelecer as especificidades do discurso fundador religioso. Nosso trabalho espera contribuir com as perspectivas contemporâneas de retorno em direção à retórica mediante o estudo dos discursos de fundação religiosa.
\end{abstract}

Palavras-chave: Semiótica. Estilo. Ethos. Discurso religioso.

\begin{abstract}
Resuming the Greimasian perspective of biblical studies, our work has as a specific objective to understand mechanisms of construction of the sense of some excerpts from the Old and New Testament, considered as scenes founding the statements of dissemination and religious fidelity. From the observation of the recurrences of the mechanisms of construction of the sense of the statements gathered through this article we try to establish the specifics of the religious founding discourse. Our work tries to contribute to the contemporary perspectives of return toward the Rhetoric study based on foundation speeches.
\end{abstract}

Keywords: Semiotic. Style. Ethos. Religious discourse.

Résumé: Reprenant la perspective grécasienne des études bibliques, notre travail a pour objectif spécifique de comprendre les mécanismes de construction du sens de certains extraits de l'Ancien et du Nouveau Testament, considérés comme des scènes fondatrices du déclarations de diffusion et de fidélité religieuse. Â partir de l'observation des récurrences des mécanismes de construction du sens des déclarations rassemblées à travers cet article, nous essayons d'établir les spécificités du discours fondateur religieux. Notre travail souhaite contribuer avec les perspectives contemporaines de retour vers la rhétorique par le biais de l'étude des discours de fondation religieuse.

Mots-clés: Sémiotique. Style. Éthos. Discours religieux. 


\section{Introdução}

O presente artigo busca a retomada da definição de um lugar, inserindo-se na especificidade dos estudos em semiótica e discurso religioso. Tendo como fundamentação teórica a semiótica discursiva e seus recentes desdobramentos tensivos (ZILBERBERG, 2011), esta pesquisa propõe-se analisar as Sagradas Escrituras enquanto discurso fundador. Estabelecemos como recorte textual textos que materializam enunciados das Sagradas Escrituras, a narrativa bíblica de Caim e Abel, extraída do Livro de Gênesis (GN 4, 1-16) e narrativa de Atos dos Apóstolos (AT, 1-3) os quais analisamos em conformidade a metodologia analítica utilizada pela teoria semiótica, o percurso gerativo do sentido.

No que diz respeito à semiótica e ao panorama dos estudos bíblicos, cabe ressaltar que a semiótica procura distinguir-se de outras teorias do texto (históricocrítica, pragmática, etc) “e de outras problemáticas da recepção e da interpretação que se apresentam atualmente na exegese bíblica e que intervém na elaboração de reflexões teológicas" (PANIER, 1989, p. 19). A entrada da semiótica na exegese bíblica marca uma ruptura de isotopia ao incluir um horizonte epistemológico completamente diferente (Cf. CHABROL, 1980). A experiência de leitura semiótica dos enunciados bíblicos apresenta um processo enunciativo ao qual Panier (1986) denomina sob o termo "comentário". O autor define comentário, provisoriamente, como um discurso produzido a partir de outro discurso e que se apresenta como equivalente do ponto de vista do sentido (PANIER, 1986, p. 267).

As obras de Chabrol (1980), Panier (1986, 1989, 2008) e Thériault (2006) são utilizadas como bases teóricas para o presente trabalho, pois, suas obras são voltadas, respectivamente, para a semiologia narrativa dos textos bíblicos e para o discurso de interpretação no comentário bíblico, sendo estudos necessários para o desenvolvimento do presente artigo. A prática de análise empreendida e a confrontação com o corpus bíblico permite, segundo Panier (2008), a rearticulação entre certos elementos da teoria semiótica, em particular, ao que concerne à dimensão figurativa do discurso e sua relação à problemática da enunciação.

A presença da semiótica narrativa no que concerne aos estudos acerca da linguagem da religião, tem início por meio do desenvolvimento dos estudos acerca da 
interpretação de enunciados bíblicos. O processo de interpretação e análise do enunciado bíblico é entendido como um processo de leitura. A leitura é vista como um processo enunciativo. A leitura para Chabrol (1980, p. 3) refere-se a um perder-se o texto e o sentido, de maneira que em seu lugar passamos a constituir um "sujeito desejando saber". Esse sujeito, em sua busca, não se pauta meramente em conformidade às premissas do enunciado elementar proposto pela semiótica em busca de seu objeto de valor, mas do próprio desejo. Temos, assim, "um saber sobre o desejo que instaura essa relação de interlocução em que se faz sua leitura" (CHABROL, 1980, p. 3). Estabelece-se, assim, conforme o autor, uma relação fundadora de um narrador e de um leitor textuais. Essa primeira relação, prevista no plano da enunciação, também pode ser concebida no plano do enunciado, mediante a associação entre destinador e destinatário.

A inclusão dos estudos referentes ao âmbito religioso na semiótica greimasiana coincidem com a publicação da obra Du Sens (GREIMAS, 1970). Cabe destacar, a importância de uma seção de três dias realizada no Grand Semináire de Versailles, em setembro de 1968, como o marco inaugural dos estudos em semiótica bíblica. Assim sendo, a presença da semiótica no debate do campo de estudos exegéticos tem início na França, a partir do Congresso de 1969 da Associação Bíblica Francesa para o estudo da Bíblia (A.C.F.E.B). Os debates provenientes desse encontro foram publicados sob o título Exégèse et Hermenéutique, Paris, Seuil, Col. Parole de Dieu, 1971. Esses estudos tiveram posterior desenvolvimento em Lyon, por meio da criação, por iniciativa de J. Delorme e J. Calloud, do Centre pour l'Analise Du Discours Religieux (CADIR), com a publicação do periódico Sémiotique et Bible.

No que concerne ao âmbito brasileiro, à maioria das publicações em semiótica e discurso religioso, detém-se em teses e dissertações, das quais cabe destacar Pietroforte (1997); Jadon (2009); Postal (2010), Demarchi (2015) e Cardoso (2017). No que tange à publicação de livros da área, temos a seguinte publicação: Mariza B. T Mendes. No Princípio era o poder. São Paulo: Annablume, 2009. Dentre os artigos e publicações de maior relevância no Brasil, considerando-se, sobretudo, as publicações dos últimos cinco anos, podemos citar: Lima (2013) e Cardoso (2014, 2015). Assim sendo, estudos referentes ao campo discursivo religioso no âmbito semiótico requerem maior aprofundamento e explicitação. 
Retomando a perspectiva greimasiana de estudos bíblicos, tal como exposta por Thériault (2006) e Panier (2008), nosso trabalho tem como objetivo específico depreender mecanismos de construção do sentido de alguns excertos extraídos do Antigo e do Novo Testamento, tidos como cenas fundadoras dos enunciados de divulgação e de fidelização religiosa.

\section{Análise Semiótica dos textos bíblicos: a narrativa bíblica de Caim e Abel (Gn 4, 1-16) T2}

A análise não poderia deixar de incluir o livro de Gênesis (Gn 4, 1-16, BÍBLIA SAGRADA, CNBB, 2007, p. 18). A tradição judaica designa esse livro pelas palavras iniciais bereshit "no princípio", o que remete ao seu significado enquanto "origem" (do mundo e da humanidade).

A narrativa bíblica de Caim e Abel (Gn 4, 1-16) institui-se como fonte primeira e fiadora do discurso instrucional do enunciado da encíclica “Evangelium Vitae”, graças ao caráter de autoridade proporcionado pela Palavra Revelada. A encíclica apresenta esta narrativa bíblica como o relato inaugural da violência contra a vida.

Reproduzimos, abaixo, o excerto da encíclica que apresenta o discurso fundador de Gênesis por meio do procedimento interdiscursivo da citação. Dessa forma, procedemos à análise semiótica do discurso da narrativa bíblica citado por esse enunciado.

O Evangelho da vida, que ressoa, logo ao princípio, com a criação do homem à imagem de Deus para um destino de vida plena e perfeita (cf. Gn 2, 7; Sab 9, 2-3), vê-se contestado pela experiência dilacerante da morte que entra no mundo, lançando o espectro da falta de sentido sobre toda a existência do homem. A morte entra por causa da inveja do diabo (cf. Gn 3, 1.4-5) e do pecado dos primeiros pais (cf. Gn 2, 17; 3, 17-19). E entra de modo violento, através do assassínio de Abel por obra do seu irmão: "Logo que chegaram ao campo, Caim levantou a mão contra o irmão Abel e matou-o" $(G n 4,8)$. Este primeiro assassínio é apresentado, com singular eloquência, numa página paradigmática do Livro do Gênesis: página transcrita cada dia, sem cessar e com degradante repetição, no livro da história dos povos. Queremos ler de novo, juntos, esta pagina bíblica, que, apesar do seu aspecto arcaico e extrema simplicidade, se apresenta riquíssima de ensinamentos.

Abel foi pastor; e Caim, lavrador. Ao fim de algum tempo, Caim apresentou ao Senhor uma oferta de frutos da terra. Por seu lado, Abel ofereceu primogênitos do seu rebanho e as gorduras deles. O Senhor olhou favoravelmente para Abel e para a sua oferta, mas não olhou para Caim nem para a sua oferta. Caim ficou muito irritado e o rosto transtornou-se-lhe. $O$ Senhor disse a Caim: "Porque estás zangado e o teu rosto abatido? Se procederes bem, 
certamente voltarás a erguer o rosto; se procederes mal, o pecado deitar-se-á à tua porta e andará a espreitar-te. Cuidado, pois ele tem muita inclinação para ti, mas deves dominá-lo". Entretanto, Caim disse a Abel, seu irmão: "Vamos ao campo". Porém, logo que chegaram ao campo, Caim levantou a mão contra o irmão Abel e matou-o.O Senhor disse a Caim: "Onde está Abel, teu irmão?" Caim respondeu: "Não sei dele. Sou, porventura, guarda do meu irmão?" O Senhor replicou: "Que fizeste? A voz do sangue do teu irmão clama da terra até Mim. De futuro, serás maldito sobre a terra que abriu a sua boca para beber da tua mão o sangue do teu irmão. Quando a cultivares, negar-te-á as suas riquezas. Serás vagabundo e fugitivo sobre a terra". Caim disse ao Senhor: "A minha culpa é grande demais para obter perdão! Expulsas-me hoje desta terra; obrigado a ocultar-me longe da tua face, terei de andar fugitivo e vagabundo pela terra, e o primeiro a encontrar-me matar-me-á".O Senhor respondeu: "Não, se alguém matar Caim, será castigado sete vezes mais". E o Senhor marcou-o com um sinal, a fim de nunca ser morto por quem o viesse a encontrar. Caim afastou-se da presença do Senhor e foi residir na região de Nod, ao oriente do Éden » (Gn 4, 2-16) (JOAO PAULO II, 2005, p.18-19, grifos da própria citação).

Tomando por base o enunciado fundador, apreendido de forma intertextual no enunciado da encíclica (divulgação religiosa), observamos que a oposição semântica fundamental é estabelecida entre os termos contrários (vida e morte) e seus contraditórios (não-morte e não-vida), que se relacionam, por sua vez, aos termos integração e transgressão. O termo "morte" é representado pelo domínio das pulsões individuais do indivíduo e o termo "vida" pelo domínio sagrado da religião e da comunhão com os valores propostos pelo enunciador divino.

Os termos do quadrado semiótico são axiologizados dentro da ideologia católica da seguinte forma: os termos "vida" e "integração" são axiologizados com valores eufóricos e os termos “morte" e "transgressão" são axiologizados com valores disfóricos.

Ao adotarmos a posição do narrador da narrativa bíblica de Caim e Abel, vemos que a operação que vai da não transgressão à integração manifesta uma tendência euforizante, por oposição à operação que vai da não integração à transgressão, efetuada na narrativa, e de tendência disforizante.

Abel foi pastor; e Caim, lavrador. Ao fim de algum tempo, Caim apresentou ao Senhor uma oferta de frutos da terra. Por seu lado, Abel ofereceu primogênitos do seu rebanho e as gorduras deles. (Gn 4, 2-16) (JOAO PAULO II, 2005, p.18-19) (Não transgressão integração).

O Senhor olhou favoravelmente para Abel e para a sua oferta, mas não olhou para Caim nem para a sua oferta. Caim ficou muito irritado e o rosto transtornou-se-lhe. (Gn 4, 216) (JOAO PAULO II, 2005, p.18-19) (Não integração - transgressão).

Observamos, na narrativa bíblica, a presença da disforia que marca a passagem das continuidades às descontinuidades com a geração das tensões. A narrativa se 
desenvolve por meio de uma contenção inicial (parada da continuação), "O Senhor olhou favoravelmente para Abel e para a sua oferta, mas não olhou para Caim nem para a sua oferta" (Gn 4, 2-16) (JOAO PAULO II, 2005, p.18-19), na qual o sujeito, ao não ser recompensado e movido pelo ciúme, nega o contrato de manipulação exercido pelo destinador divino.

A transgressão "Caim levantou a mão contra o irmão Abel e matou-o" realiza-se por meio da retenção (continuação da parada), expressa pelo antiprograma narrativo desenvolvido pelo sujeito ao executar seu próprio irmão, culminando na distensão (parada da parada) com o reconhecimento da culpa pela performance executada: "A minha culpa é grande demais para obter perdão! Expulsas-me hoje desta terra; obrigado a ocultar-me longe da tua face, terei de andar fugitivo e vagabundo pela terra, e o primeiro a encontrar-me matar-me-á" (Gn 4, 2-16) (JOAO PAULO II, 2005, p.18-19).

Inicialmente, no percurso do destinador-manipulador, temos uma espécie de contrato (manipulação pressuposta) entre as funções sintáticas de destinadormanipulador (o Senhor) e de destinatário-manipulado (irmãos: Caim e Abel). Segundo esse contrato pressuposto, o "Senhor" manipula os actantes-sujeitos (irmãos) a deverfazer, ou seja, a dever apresentar sacrifícios ao Senhor.

O acordo entre o destinador-manipulador e o destinatário-sujeito pressupõe que ambos partilhem do mesmo quadro axiológico de valores. A performance se realiza, os actantes-sujeitos cumprem o contrato e apresentam sacrifícios ao Senhor. Abel oferece os "primogênitos do rebanho e a gordura deles" e Caim proporciona a "oferta de frutos da terra”.

Após o percurso de ação do sujeito, efetiva-se a atividade do destinador-julgador. Este, ao realizar o seu fazer interpretativo, estabelece a seguinte sanção cognitiva de reconhecimento: Abel é reconhecido por sua performance, enquanto Caim não obtém reconhecimento: "O Senhor olhou favoravelmente para Abel e para a sua oferta, mas não olhou para Caim nem para a sua oferta" (Gn 4, 2-16) (JOAO PAULO II, 2005, p.18-19).

No percurso do sujeito, Caim desempenha vários papéis actanciais: sujeito do querer-fazer (querer cumprir o contrato pressuposto), do saber-fazer e do poder-fazer (tem a competência necessária para executar a performance) e do querer-ser (quer ser recompensando). 
Ainda no percurso do destinador-manipulador, há um programa de doação de competência pressuposto. Por meio desse programa narrativo de aquisição de competência pressuposto, poder e saber são atribuídos a Caim para dominar o pecado e agir conforme os preceitos divinos. Caim tem o saber-fazer, o dever-fazer e o poder-fazer necessários para dominar o pecado.

Entretanto, efeitos de sentido afetivos ou modulações passionais orientam o percurso efetuado pelo destinatário sujeito (Caim) ao longo da narrativa.

A narrativa de "Caim e Abel" se desenvolve, inicialmente, em torno de uma expectativa fiduciária, uma espera baseada na confiança. A expectativa fiduciária, dado o caráter intersubjetivo proposto, põe o sujeito em relação a outros sujeitos $\left(S_{1} \rightarrow S_{2}\right)$.

No enunciado considerado, "Abel foi pastor; e Caim, lavrador. Ao fim de algum tempo, Caim apresentou ao Senhor uma oferta de frutos da terra. Por seu lado, Abel ofereceu primogênitos do seu rebanho e as gorduras deles”, (Gn 4, 2-16) (JOAO PAULO II, 2005, p.18-19), a expectativa fiduciária pressupõe uma relação intersubjetiva entre o "Senhor" e "Caim". Essa expectativa fiduciária de Caim relativa ao Senhor vai transformar Caim, de sujeito desejoso do reconhecimento, em sujeito disjunto com o objeto modal querer-ser reconhecido.

Temos, inicialmente, o descontentamento do sujeito, frustrado em suas esperanças, acompanhado de um estado passional definido como um "sentimento penoso", um sentimento de falta que tem como característica a necessidade de elaboração de um programa narrativo da liquidação da falta. O descontentamento se apresenta como o pivô passional ao subsumir o desenvolvimento das estruturas passionais que constituem o sintagma passional da "cólera" (GREIMAS, 1983, p. 226).

Desse modo, vemos que o percurso de variação de tensividade organiza-se segundo um aumento de tensão: relaxamento $\rightarrow$ intensão $\rightarrow$ tensão.

Essa variação de tensividade realiza, na narrativa, o seguinte percurso passional: confiança $\rightarrow$ decepção $\rightarrow$ ciúme $\rightarrow$ inveja $\rightarrow$ ira $\rightarrow$ cólera $\rightarrow$ revolta, (liquidação da falta).

Caim deixa-se manipular, por tentação, pelo antiprograma narrativo pressuposto representado pelo pecado. As paixões do ciúme, da ira, da cólera e da inveja fazem com que ele seja induzido a executar o primeiro fratricídio, na raiz da violência contra o próximo. Caim instala-se como sujeito mediante a determinação do querer-fazer, ou seja, querer liquidar a falta sofrida. A restituição da falta é dada por intermédio de um 
programa de ação pautado por um desejo de vingança. Esta, definida como a necessidade ou o desejo de se vingar, não se constitui apenas de "uma simples liquidação da falta que situaria o PN no nível da circulação dos objetos de valor, mas de uma questão entre sujeitos, dos quais, um deve ser 'indenizado moralmente' e o outro, 'punido"” (GREIMAS, 1983, p. 241).

Caim realiza-se como sujeito revoltado e, dotado das modalidades do poder-fazer e do querer-fazer, pode autoafirmar-se pela possibilidade de destruição do rival (vingança).

$\mathrm{O}$ actante sujeito sancionado negativamente se decepciona e, por meio dos percursos passionais da revolta, da inveja, da ira e do ódio adquire o poder-fazer e o querer-fazer o mal a alguém, o rival.

A rivalidade remete, de acordo com Greimas (1983, p. 174), à "situação de duas ou mais pessoas que disputam por alguma coisa (sobretudo o primeiro lugar, a primeira fileira)". Encontram-se, assim, os papéis actanciais dos sujeitos de estado concorrentes $\left(\mathrm{S}_{1} / \mathrm{S}_{2}\right)$ entre os quais circula o objeto de valor (poder-ser e querer-ser reconhecido pelo Senhor). Caim é modalizado pela paixão intersubjetiva do ciúme pelo querer-ser (possessão) e pelo dever-ser (apego). A relação entre os irmãos é movida pela rivalidade, calcada em sentimentos de inveja e ódio em Caim. A inveja de um irmão pelo outro desencadeia um estado de alma de paixões malevolentes. Dessa forma, desenvolve-se a narrativa da rivalidade entre irmãos, segundo a qual "para melhor expressar o poder soberano, absoluto e indivisível só restava a alternativa do fratricídio" (GREIMAS, 2004, p. 26).

Caim, como sujeito ressentido, revolta-se; e, munido do poder-fazer (poder transformador de estados: da disjunção à junção), cumpre a ação, com a performance do assassínio de seu irmão. Por intermédio dessa performance, Caim executa a seguinte transformação de estados: a) Abel: sujeito conjunto com a vida e com a recompensa divina passa $\mathrm{a} \rightarrow$ um sujeito em disjunção com a vida; b) Caim: sujeito disjunto com o poder-ser passa a $\rightarrow$ um sujeito conjunto com o poder-ser.

${ }^{1} \mathrm{O} P N$ de vingança permanece, não obstante, um programa de compensação, mas esta última se realiza no nível das "paixões" e o equilíbrio intersubjetivo buscado é uma espécie de equivalência passional. Se um sujeito S1 sofre, então é conveniente infringir a "pena", quer dizer, a punição e a dor, ao mesmo tempo, ao sujeito S2 para fazê-lo sofrer outro tanto. A vingança, como se vê, é a princípio um reequilíbrio de sofrimentos entre dois sujeitos antagonistas. Um tal equilíbrio de sofrimentos é um fenômeno intersubjetivo, uma regulação social das paixões (GREIMAS, 1983, p. 241).

Revista Investigações, Recife, v. 32, n. 2, p. 548 - 570 , Dezembro/2019 
Caim, ao matar Abel por ciúmes da preferência de Deus, adquire o poder-ser (soberania) necessário, concretizando o programa de liquidação da falta. Segue-se, à realização da performance, a rapidez e a aceleração da progressão do mal.

Terminado o percurso da ação do sujeito, tem início, na narrativa, o percurso do destinador-julgador e, consequentemente, da atividade de sanção. Ao efetivar o seu fazer interpretativo, o destinador-julgador avalia as etapas da narrativa executadas por Caim.

Após a pergunta do destinador-julgador “Onde está Abel, teu irmão?”, e da resposta de Caim “Não sei dele. Sou, porventura, guarda do meu irmão?”, segue a réplica do Senhor, “Que fizeste?”, com a figura da "voz do sangue do teu irmão clama da terra até Mim”. Essa figura é suficiente para o desmascaramento do sujeito por parte do destinador-julgador.

A evocação da "voz do sangue que clama do solo" possui origem na crença judaica, segundo a qual o sangue humano derramado e não coberto de terra clamaria aos céus (BRUNEL, 1997, p.139-140).

O segredo e a mentira são desmascarados pelo destinador-julgador (o Senhor). Com isso, o destinador denuncia o comportamento mentiroso e ilusório de Caim aplicando-lhe uma sanção negativa. Caim, após executar a performance do assassínio de seu irmão, é sancionado negativamente pelo destinador divino. Realiza-se, na narrativa, uma sanção cognitiva e pragmática com a punição: ser amaldiçoado por Deus, como também pela terra, que lhe recusará os seus frutos ( $\mathrm{Gn}$ 4, 11-12). Caim é punido: habitará em terras agrestes e desertas. Segue-se um PN de privação transitiva por espoliação, no qual o Senhor tira de Caim os objetos de valor "riquezas da terra" e "presença do Senhor". Caim reconhece sua culpa e realiza-se, por fim, um PN de doação de competência, no qual o Senhor dota Caim com um sinal (objeto modal), conforme o qual Caim adquire o não-poder-ser morto por quem o encontrasse.

Ressaltamos o comportamento patêmico desse enunciador, "que perdoa e condena ao mesmo tempo, gera atritos e paixões, como a inveja de Caim, que mata o irmão Abel” (MENDES, 2009, p. 12). Tomemos a afirmação de Mendes (2009), ao elaborar a análise semiótica das paixões no Antigo testamento. Vejamos como a autora evidencia a figurativização da imagem do hiperenunciador divino instaurado no enunciado: 
Instaurando-se como um "juiz implacável" e movido por um tumulto de paixões, o criador é figurativizado no discurso do Antigo Testamento como aquele que detém o poder, enquanto as criaturas que habitam o Canaã são sujeitos que também disputam o poder, sustentado nesse caso pela posse da terra prometida (MENDES, 2009, p. 12).

Com relação ao exame das estruturas discursivas do referido texto, observamos que este se realiza pela utilização de uma debreagem enunciva. As estratégias do enunciador constituem-se na ocultação do eu-aqui-agora, ancorando os movimentos do sentido nos atores do enunciado, num tempo figurativizado como o tempo do "então" e num espaço topicalizado como o espaço do "alhures”: “Abel foi pastor; e Caim, lavrador. Ao fim de algum tempo, Caim apresentou ao Senhor uma oferta de frutos da terra" (Gn 4, 2-16). Tem-se a emergência dos atores do enunciado por meio de um discurso que parece se enunciar sozinho. A história bíblica considerada, ao ser apoiada no texto figurativo, é pautada por uma construção mítica, segundo a qual o crime, persistente fato social, é representado em nossa cultura pelo episódio bíblico de Caim e Abel.

No que diz respeito aos procedimentos de actorialização presentes no enunciado fundador bíblico considerado, notamos a presença de um narrador implícito que dá voz aos actantes do enunciado, instalando-os no discurso por meio de uma debreagem interna enunciativa de segundo grau. Essa debreagem dá-se pela presença do discurso direto $^{2}$ instalado entre aspas, que instaura o diálogo entre os actantes representados pelo Senhor e Caim.

O Senhor disse a Caim: "Onde está Abel, teu irmão?" Caim respondeu: "Não sei dele. Sou, porventura, guarda do meu irmão?" (Gn 4, 2-16) (JOAO PAULO II, 2005, p.18-19, grifos nossos).

Desse modo, o discurso direto é resultante da debreagem interna enunciativa de segundo grau, por meio da qual o narrador delega voz aos actantes do enunciado e projeta duas instâncias enunciativas autônomas, concernentes à presença de dois atos enunciativos, duas vozes: a do narrador e a do personagem (interlocutor). Mediante

2"O discurso direto é resultado de uma debreagem interna (em geral de segundo grau), em que o narrador delega voz a um actante do enunciado. Possui duas instâncias enunciativas, dois níveis de eu: o do narrador e o do interlocutor. O discurso direto é um simulacro da enunciação construído por intermédio do discurso do narrador. [...] O discurso direto, em geral, cria um efeito de sentido de realidade, pois dá a impressão de que o narrador está apenas repetindo o que disse o interlocutor" (FIORIN, 2002, p. 72-74).

Revista Investigaçũes, Recife, v. 32, n. 2, p. 548 - 570, Dezembro/2019 
emprego do discurso direto, recria-se a situação da enunciação por intermédio do narrador.

Para fazer emergir os atores do enunciado, ao introduzir o discurso direto, o narrador se enuncia por meio de um verbo dicendi (de dizer) ${ }^{3}$ :

O Senhor disse a Caim: "Onde está Abel, teu irmão?" Caim respondeu: "Não sei dele. Sou, porventura, guarda do meu irmão?" (JOAO PAULO II, 2005, p. 19, grifos nossos).

Com relação à temporalização, notamos, na fala do narrador, a presença de verbos no pretérito perfeito 2, que indicam a pontualidade e o término das ações executadas, tal como:

Abel foi pastor; e Caim, lavrador. Ao fim de algum tempo, Caim apresentou ao Senhor uma oferta de frutos da terra. Por seu lado, Abel ofereceu primogênitos do seu rebanho e as gorduras deles. O Senhor olhou favoravelmente para Abel e para a sua oferta, mas não olhou para Caim nem para a sua oferta (JOAO PAULO II, 2005, p. 19, grifos nossos).

A ambientação correspondente aos espaços nos quais se movimentam os personagens encontra-se organizada no enunciado considerado em função de dois pontos instalados no interior do texto: o “campo" no qual se desenvolve o assassínio de Abel (espaço do fratricídio) e a região de Nod, ao oriente do Éden (espaço de afastamento e errância). A partir desses pontos instalados no interior do texto, há uma movimentação dos personagens nesse espaço. Observamos a modificação de suas posições dentro dessa categoria espacial, com o movimento de afastamento pelo qual Caim é punido, sendo obrigado a ocultar-se diante do Senhor e habitar a região de Nod.

Verificamos, portanto, que a narrativa bíblica de Caim e Abel caracteriza-se como um texto figurativo, na medida em que: "trata de personagens concretizados semanticamente que atuam num tempo e espaço específicos” (CARVALHO, 2005, p. 43).

Vejamos como os valores assumidos pelo sujeito da narrativa são disseminados segundo percursos temáticos e revestidos por percursos figurativos. Elencamos, a seguir, os temas que compõem a narrativa e, em seguida, explicitamos o revestimento figurativo decorrente.

3“O discurso reportado deve ser marcado, para que o enunciatário perceba a distinção entre discurso citante e citado. As marcas são diferentes no texto oral ou escrito. A marca mais importante, sem dúvida, é o verbo introdutor, em geral um verbum dicendi” (FIORIN, 2002, p.77, grifo do autor).

Revista Investigações, Recife, v. 32, n. 2, p. 548 - 570, Dezembro/2019 
a) Inimizade entre irmãos (configuração discursiva da rivalidade). Esse tema recebe o investimento figurativo pautado pela oposição entre os atores (Caim e Abel). A oposição entre eles desenvolve-se mediante duas isotopias figurativas distintas: agricultura (papel temático do lavrador) em Caim vs. pecuária (papel temático de pastor) em Abel. Destaque das figuras da isotopia agrícola: "lavrador", "oferta de frutos da terra"; isotopia pecuária: "primogênitos do seu rebanho"; "gorduras deles".

b) Rivalidade entre o bom e o mau. Esse tema recebe o investimento figurativo da rivalidade entre os irmãos. Caim é representado como aquele que tem inclinação ao pecado, por oposição a Abel, considerado bom e reconhecido pelo Senhor.

c) Oposição entre o Bem e o Mal. O narrado apresenta um caráter binário, segundo o qual a narrativa bíblica se constrói mediante uma série de categorias em oposição. $\mathrm{O}$ texto orienta a realidade consoante dois princípios principais: o bem, proveniente da integração ao sistema de valores propostos por Deus, e o mal, proveniente de entidades demoníacas. O mal é figurativizado como o pecado, entendido como transgressão da lei divina.

d) Livre preferência de Deus pelos mais novos e fracos: figurativizado pela preferência do Senhor por Abel.

e) Fé no sacrifício: figurativizado pelo olhar favorável demonstrado pelo Senhor às ofertas de Abel.

f) Onisciência divina: figurativizado pela "voz do sangue do teu irmão clama da terra até mim”, de acordo com a qual Deus já sabia que Caim havia cometido o pecado.

g) Manutenção dos valores divinos: figurativizado pelo bem proceder. Caim estaria, inicialmente, dotado do saber-fazer, dever-fazer e poder-fazer necessários para dominar o pecado.

h) Pecado original (crime). Figurativizado pelo fratricídio: "terra que abriu a sua boca para beber da tua mão o sangue do teu irmão".

i) Errância (configuração discursiva da errância). Figurativizada por: "andar fugitivo"; "vagabundo; "região de Nod, ao oriente do Éden".

j) Punição divina: figurativizado com a maldição imposta por Deus a Caim: "De futuro, serás maldito sobre a terra";

k) Nova integração divina (redenção). Figurativizado por: "reconhecimento da culpa"; "sinal".

\section{Análise Semiótica da Narrativa de Atos dos Apóstolos (At, 1-3)}

Reproduzimos, abaixo, um excerto da narrativa considerada para análise ${ }^{4}$ :

${ }^{4}$ Os números antes de cada segmento correspondem à indicação do número do capítulo em negrito (por exemplo, Atos dos Apóstolos, capítulo 1) e dos versículos bíblicos, indicados em sobrescrito.

Revista Investigações, Recife, v. 32, n. 2, p. 548 - 570, Dezembro/2019 
Bíblia Sagrada: Atos dos Apóstolos (At, 1-3)

\section{"EM JERUSALÉM, NA JUDÉIA E NA SAMARIA"}

\section{A promessa do Espírito Santo}

1. ${ }^{1 .}$ No meu primeiro livro, ó Teófilo, tratei de tudo que Jesus fez e ensinou, desde o começo ${ }^{2}$ até o dia em que foi elevado ao céu, depois de ter dado instruções, pelo Espírito Santo, aos apóstolos que havia escolhido. ${ }^{3 \cdot}$ Depois da sua paixão, Jesus mostrou-se vivo a eles, com numerosas provas. Apareceu-lhes por um período de quarenta dias, falando do Reino de Deus. ${ }^{4}$ Ao tomar a refeição com eles, deu-lhes esta ordem: "Não vos afasteis de Jerusalém, mas esperai a realização da promessa do Pai, da qual me ouvistes falar, quando eu disse: ${ }^{5}$. 'João batizou com água; vós, porém, dentro de poucos dias sereis batizados com o Espírito Santo". [...] (At, 1, 1-2, BÍBLIA SAGRADA, CNBB, 2007).

Atos dos Apóstolos constitui um dos livros do Novo Testamento, em seguida aos Evangelhos. Nesse discurso, temos a narração do seguimento da história de Jesus expressa nos Evangelhos, sobretudo o de Lucas. Este é tido como um primeiro livro do qual a narrativa de Atos resume o objeto e retoma os últimos acontecimentos (aparição do ressuscitado e ascensão), encadeando-os à sequência do relato.

Procuramos demonstrar os mecanismos de construção do sentido do texto que fazem com que a narrativa de Atos possa ser considerada o primeiro relato de divulgação dos ideais cristãos.

Atos dos Apóstolos, presente no Novo Testamento, apresenta-se como um livro histórico de autoria do evangelista Lucas. O gênero desse discurso caracteriza-o como uma narrativa de atos ou práticas, tal como a literatura helenística reconhecia as narrativas de atos ou práticas de pessoas famosas, como Aníbal e Alexandre o Grande. A narrativa dos Atos apostólicos, de estilo lacônico e linguagem polida do narrador, assinala o caráter de testemunho e de conclamação da fé.

A tradição atribui a Lucas a autoria do terceiro Evangelho e dos Atos dos Apóstolos. Entretanto, conforme ressalta Kurtz (1999, p. 143), há muitas controvérsias entre os biblistas a respeito de quem teria escrito o Evangelho, atribuído a Lucas, e os Atos dos Apóstolos.

Retomemos esses debates sob a questão teórica da autoria, tão cara aos estudos discursivos. A noção de autor compõe, para Foucault (1997, p. 33), “o momento forte de individuação na história das ideias, dos conhecimentos, das literaturas, na história da filosofia moderna, e na das ciências". A relação do texto com o seu autor aponta para essa figura que é, ao mesmo tempo, exterior e anterior. Quando pensamos no nome do 
autor "Lucas", ele não se estabelece como uma referência pura e simples. Ele é um nome próprio, palavra equivalente a uma série de atributos definidos em torno deste: o autor do Evangelho de Lucas e da Narrativa de Atos dos Apóstolos. Temos, segundo Foucault (1997, p. 42), o nome próprio e o nome do autor situados nos polos da descrição e da designação. Entretanto, o nome do autor não se configura como um nome próprio exatamente como os outros. Foucault (FOUCAULT, 1997, p. 44) ressalta a singularidade paradoxal da autoria, afinal, ela não é simplesmente o elemento de um discurso. Ela assegura uma função classificativa, pois permite reagrupar, delinear e opor textos a outros. A autoria serviria, portanto, para caracterizar o modo de ser do discurso. Procuraremos delinear, assim, mediante um conjunto de traços recorrentes do plano do conteúdo e do plano de expressão, a imagem do narrador de Atos, enquanto efeito de identidade próprio a esse discurso. Como se caracteriza o éthos, a imagem do narrador do texto singular da narrativa de Atos?

A narrativa bíblica de Atos dos Apóstolos, embora seja considerada o primeiro relato das origens do cristianismo, não pode ser caracterizada como uma historiografia,

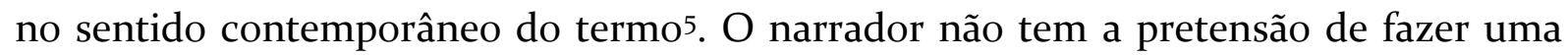
reconstituição científica dos fatos, mas, baseando-se em fontes fidedignas, procura evocar o sentido daquilo que aconteceu, além de prestar homenagem aos primeiros evangelizadores e fundadores das Igrejas Cristãs (BÍBLIA SAGRADA, CNBB, 2007, p. 1340).

Que expectativas os leitores do século I tinham sobre um livro que se propunha historiográfico, isto é, que procura registrar os acontecimentos e fatos históricos de seu tempo? Quais códigos de comunicação ligavam o enunciador aos enunciatários pressupostos por esse discurso? A que regras obedeciam à escritura da história na sociedade romana à qual Lucas pertencia? Essas são algumas questões sobre as quais se debruça Marguerat (2003, p. 24), exegeta que, amparado pelos métodos de interpretação da crítica histórica e da narratologia, procura depreender o sentido da narrativa bíblica de Atos, enquanto primeira história do cristianismo. Ainda que nosso arcabouço teórico seja orientado pela semiótica greimasiana, não deixaremos de vislumbrar alguns dos

${ }^{5} \mathrm{O}$ sentido contemporâneo de historiografia diz respeito ao trabalho científico que tem como centro o trabalho do historiador designado a registrar os acontecimentos e fatos históricos, em correspondência ao princípio da objetividade.

Revista Investigaç̃̃es, Recife, v. 32, n. 2, p. 548 - 570, Dezembro/2019 
desenvolvimentos do pensamento do autor, na medida em que eles possam contribuir para a caracterização do éthos do narrador de Atos.

Para o autor, "fazer história é procurar as causas dos acontecimentos (o que nos leva de volta à noção de enredo, pois este consiste em estabelecer uma relação de causa e efeito entre os fatos)" (MARGUERAT, 2003, p. 24). Por historiografia entenderíamos, então, a busca de causalidades.

O prefácio do livro de Atos instaura no enunciado um endereçamento a um sujeito. Temos a referência ao narratário (Teófilo), indicada logo no início da narrativa: “No meu primeiro livro, ó Teófilo”, (At, 1, 1-2, BÍBLIA SAGRADA, CNBB, 2007, p. 1342). Esse estilo prefacial pertencente à prosa técnica confirmaria a correspondência do escrito lucano ao padrão da historiografia greco-romana.

Para o autor, o leitor familiarizado com a narrativa de Atos encontraria aqui uma das normas, segundo as quais, Lucas teria subscrito sua narrativa.

Outro traço fundamental da historiografia greco-romana, apontado pelo autor, é o seu papel edificador e a sua importância na educação.

Como poderemos depreender, na materialidade discursiva do enunciado, os traços que remetem a essa imagem de si? Ao concebermos o discurso como um conjunto de procedimentos argumentativos utilizados pelo enunciador para convencer o enunciatário, compreenderemos, mediante a análise a seguir, como esses procedimentos são empregados pelo enunciador para fazer-crer como verdadeiro seu enunciado e viabilizar, por parte do enunciatário (leitores cristãos), a adesão às normas e aos modelos a serem seguidos. Deduziremos esses traços pela análise dos procedimentos argumentativos empregados pelo enunciado.

No que diz respeito à análise narrativa de Atos, teremos Lucas como o destinador que busca transmitir um objeto de valor cognitivo: o saber a respeito da história da Igreja.

Mais do que um relato histórico (narrativa dos primórdios da Igreja), o texto se constitui como a transmissão do $\mathrm{O}_{\mathrm{v}}$ salvação para o sujeito: transmissão da boa nova, comunicação, divulgação.

Discursiviza-se, no enunciado, o plano divino da salvação e de como todos os acontecimentos expostos são respostas autênticas às promessas de Israel. 
Está acontecendo o que foi anunciado pelo profeta Joel: ${ }^{17 .}$ "Nos últimos dias, diz o Senhor, derramarei do meu Espírito sobre toda carne, e vossos filhos e filhas profetizarão, os vossos jovens terão visões e os vossos anciãos terão sonhos; ${ }^{18}$. mesmo sobre os meus escravos e escravas derramarei do meu Espírito, naqueles dias, e profetizarão. ${ }^{19} \mathrm{E}$ mostrarei prodígios no céu, em cima, e sinais na terra, em baixo, sangue e fogo e nuvem de fumaça. ${ }^{20}$. O sol se transformará em trevas e a lua, em sangue, antes que venha o grande e glorioso dia do Senhor. ${ }^{21 .} \mathrm{E}$ todo aquele que invocar o nome do Senhor será salvo" (At, 2, 16-21, BÍBLIA SAGRADA, CNBB, 2007, p. 1344).

Podemos caracterizar esse discurso como o primeiro relato de divulgação dos ideais cristãos da Igreja Primitiva. Temos, assim, mediante a sequência da narrativa a exposição de como Pedro, Paulo e outros missionários cristãos realizaram a obra de Jesus de acordo com o seu plano salvífico. Ele demonstra a continuidade do relato entre a narrativa referente a Jesus e os apóstolos, dado como anúncio profetizado pelo Antigo Testamento.

No que concerne aos procedimentos argumentativos empregados, observamos a presença da argumentação pelo exemplo e a aquisição do $\mathrm{O}_{\mathrm{v}}$ salvação por parte do sujeito - fiel, caso este siga os modelos estabelecidos e aja como um verdadeiro cristão por meio da adequada propagação do evangelho.

Se tomarmos como base os procedimentos argumentativos referentes às ligações que fundam a estrutura do real, estabelecidos por Perelman e Olbrechts-Tyteca (2005, p. 413), no que diz respeito ao fundamento pelo caso particular, a estratégia argumentativa empregada é a argumentação pelo exemplo.

A vida da primeira comunidade, um caso particular, é colocada como um exemplo, um modelo de conduta a ser imitada (PERELMAN; OLBRECHTS-TYTECA, p. $414)$.

42. Eles eram perseverantes em ouvir o ensinamento dos apóstolos, na comunhão fraterna, na fração do pão e nas orações. ${ }^{43}$. Apossava-se de todos o temor, e pelos apóstolos realizavam-se numerosos prodígios e sinais. ${ }^{44}$. Todos os que abraçavam a fé viviam unidos e possuíam tudo em comum; ${ }^{45}$. vendiam suas propriedades e seus bens e repartiam o dinheiro entre todos, conforme a necessidade de cada um. ${ }^{46}$. Perseverantes e bem unidos, freqüentavam diariamente o templo, partiam o pão pelas casas e tomavam a refeição com alegria e simplicidade de coração. ${ }^{47 .}$ Louvavam a Deus e eram estimados por todo o povo. E, cada dia, o Senhor acrescentava a seu número mais pessoas que seriam salvas (At, 2, 42-47, BÍBLIA SAGRADA, CNBB, 2007, p. 1345).

O comportamento dos membros da comunidade é exemplar por constituir um simulacro intersubjetivo da perseverança na realização de desígnios divinos. Temos a 
manutenção da aquisição do $\mathrm{O}_{\mathrm{v}}$ "graça divina" por parte daqueles que forem perseverantes em ouvir o ensinamento dos apóstolos.

Enquanto a comunidade adepta ao seguimento dos apóstolos é posta como modelo pelo exemplo, Judas constitui-se como o antimodelo de conduta a ser seguida. "Se a referência a um modelo possibilita promover certas condutas, a referência a um contraste, a um antimodelo permite afastar-se delas" (PERELMAN; OLBRECHTSTYTECA, 2005, p. 417, grifo da citação original).

Pedro levantou-se no meio dos irmãos e disse: 16. "Irmãos, era necessário que se cumprisse o que o Espírito Santo, por meio de Davi, na Escritura, anunciou acerca de Judas, que se tornou o guia daqueles que prenderam Jesus. ${ }^{17}$. Ele era um dos nossos e foi incumbido do mesmo ministério ${ }^{18}$. Ele até comprou um campo com o salário da maldade, mas caiu morto, de bruços, arrebentado pelo meio, espalhando-se todas as suas vísceras. ${ }^{19 .} \mathrm{O}$ fato se tornou conhecido de todos os habitantes de Jerusalém. Por isso, aquele campo chamase na língua deles Hacéldama, quer dizer, Campo do Sangue (At, 1, 15-19, BÍBLIA SAGRADA, CNBB, 2007, p. 1345).

Judas é instaurado como o antiexemplo, modelo de conduta a ser rechaçado. A presença do contraexemplo faz parte da retórica didatizante desse discurso. A argumentação, ao contrapor contraexemplos às figuras exemplares, pode ser relacionada à necessidade proposta pelo discurso fundador bíblico de ensinar a "amar" e a "temer" a Deus. Temos uma manipulação por intimidação. A presença do contraexemplo a ser rechaçado (não querer ser) valoriza, pelo contraste, os demais sujeitos, tidos como exemplos a serem seguidos (querer ser).

O discurso fundador dos Atos dos Apóstolos apresenta uma aspectualização incoativa ao se estabelecer como referência básica para a instituição do domínio de divulgação dos ideais cristãos, em cumprimento às últimas palavras de Jesus no momento de sua ascensão:

Mas recebeis o poder do Espírito Santo que virá sobre vós, para serdes minhas testemunhas em Jerusalém, por toda a Judéia e Samaria, e até os confins da terra (At, 1, 8, BÍBLIA SAGRADA, CNBB, 2007, p. 1342).

Essa conjunção com o objeto de valor modal $\left(\mathrm{O}_{\mathrm{m}}\right)$, representado pelo poder do Espírito Santo, dá-se por meio do programa narrativo de doação de competência realizado pela figura de Jesus Cristo, mediante a intermediação do Espírito Santo. A instituição do sacramento do batismo confere o poder necessário para que os apóstolos possam se tornar verdadeiros evangelizadores: "Ser testemunhas em Jerusalém”, “em 
toda a Judéia e Samaria”, "até os confins da terra”. Temos a narrativa de divulgação dos ideais cristãos, por intermédio do anúncio da palavra de Deus e da difusão do cristianismo.

Realizamos, a seguir, o exame da sintaxe discursiva do referido enunciado instrucional dentro do discurso fundador. Estudamos as marcas da enunciação no enunciado, utilizando-nos dos procedimentos de actorialização, temporalização e espacialização, referentes à instauração de pessoas, tempo e espaço no discurso.

No que diz respeito aos procedimentos de actorialização presentes nesta parte da narrativa bíblica, temos a presença de um narrador explícito (Lucas) que se dirige a certo Teófilo, narratário instaurado no enunciado.

No meu primeiro livro, ó Teófilo, tratei de tudo o que Jesus fez e ensinou, desde o começo até o dia em que foi elevado ao céu, depois de ter dado instruções, pelo Espírito Santo, aos apóstolos que havia escolhido (At, 1, 1-2, BÍBLIA SAGRADA, CNBB, 2007, p. 1342).

Por meio de uma debreagem interna enunciativa de segundo grau, apresentamos a instauração do diálogo entre os actantes representados por Jesus e os Apóstolos.

Então, os que estavam reunidos perguntaram a Jesus: "Senhor, é agora que vais restabelecer o Reino para Israel?" 7 . Jesus respondeu: "Não cabe a vós saber os tempos ou momentos que o Pai determinou com a sua autoridade. ${ }^{8}$. Mas recebereis o poder do Espírito Santo que virá sobre vós, para serdes minhas testemunhas em Jerusalém, por toda a Judéia e Samaria, e até os confins da terra" 9.(At, 1, 1-9, BÍBLIA SAGRADA, CNBB, 2007, p. 1343).

Notemos a emergência dos atores do enunciado, introduzidos em discurso direto pelo narrador por meio de um "verbo de dizer": "Então, os que estavam reunidos perguntaram a Jesus", "Jesus respondeu (...)" (grifos nossos).

No que tange aos mecanismos de temporalização presentes no enunciado, verificamos a utilização do pretérito perfeito 2, que procura assinalar um aspecto acabado, pontual às ações.

No meu primeiro livro, ó Teófilo, tratei de tudo que Jesus fez e ensinou, desde o começo (At, 1, 1, BÍBLIA SAGRADA, CNBB, 2007, p. 1342, grifos nossos).

De fato, Deus ressuscitou este mesmo Jesus, e disso todos nós somos testemunhas (At, 2, 32, BÍBLIA SAGRADA, CNBB, 2007, p. 1342, grifos nossos). 
Ainda no que concerne à temporalização, notamos a presença de advérbios de tempo articulados em um sistema enuncivo, organizados em torno de um momento de referência (pretérito ou futuro), inscrito no enunciado (FIORIN, 2002, p. 162).

Esse sistema se exprime pelo uso do advérbio "então" que assinala a concomitância ao marco temporal pretérito instaurado no enunciado:

"Então os apóstolos deixaram o monte das Oliveiras" (At, 1, 12, BÍBLIA SAGRADA, CNBB, 2007, p. 1343, grifos nossos).

"Então apareceram línguas como de fogo que se repartiram e pousaram sobre cada um deles" (At, 2, 3, BÍBLIA SAGRADA, CNBB, 2007, p. 1343, grifos nossos).

Mantém-se o pretérito perfeito 2:

"Depois da sua paixão, Jesus mostrou-se vivo a eles, com numerosas provas" (At, 1, 3, BÍBLIA SAGRADA, CNBB, 2007, p. 1343, grifos nossos).

"De repente, veio do céu um ruído como de um vento forte, que encheu toda a casa em que se encontravam" (At, 2, 3, BÍBLIA SAGRADA, CNBB, 2007, p. 1344, grifos nossos).

No que diz respeito à subversão temporal, observamos a instauração da concomitância 1 pela concomitância 2 (presente pelo pretérito perfeito 2).

E agora, exaltado pela direita de Deus, ele recebeu o Espírito Santo que fora prometido pelo Pai e o derramou, como estais vendo e ouvindo. ${ }^{34}$. Pois Davi não subiu ao céu, mas ele diz: 'Disse o Senhor ao meu Senhor: senta-te à minha direita' [...]" (At, 2, 33-36, BÍBLIA SAGRADA, CNBB, 2007, p. 1345, grifos nossos).

A espacialização reconstrói a cena da enunciação por meio do uso de uma debreagem enunciva mediante a figurativização do espaço instaurado no interior da história bíblica. Temos dois pontos instituídos dentro do texto: "o monte das Oliveiras" e o retorno dos personagens à "Jerusalém".

12. Então os apóstolos deixaram o monte das Oliveiras e voltaram para Jerusalém, à distância que se pode andar num dia de sábado. ${ }^{13}$. Entraram na cidade e subiram para a sala de cima onde costumavam ficar (At, 1, 12-13, BÍBLIA SAGRADA, CNBB, 2007, p. 1343, grifos nossos).

É interessante notar que a duração temporal da transposição espacial de um ponto a outro no enunciado não é medida cronologicamente, mas espacialmente "à distância que se pode andar num dia de sábado”. 
No que concerne à temática dos Atos (1-12), observamos a narração da vida da primeira comunidade reunida em torno de Pedro (primórdios do cristianismo) e o início de sua ascensão (primeiro relato de divulgação dos ideais cristãos) graças às ações missionárias de Felipe, dos Helenistas e do Próprio Pedro. Temos, portanto, no trecho em análise, a temática da origem e crescimento da Igreja em Jerusalém por intermédio do Espírito.

No que diz respeito ao modo específico de axiologizar valores, correspondentes aos preceitos de uma determinada formação ideológica, no caso, os valores propugnados pela ideologia religiosa católica e que serão materializados no nível discursivo do percurso gerativo do sentido, obtemos no enunciado a presença dos seguintes temas: a) realização do plano divino de salvação; b) ação do Espírito Santo por intermédio dos apóstolos; c) salvação do povo de Deus; d) triunfo dos ideais cristãos; e) orientação divina do caminho cristão.

Com base nesses pressupostos, os resultados de nossa análise incidem na caracterização do enunciado divulgador bíblico de Atos como um enunciado definido segundo os parâmetros da "história da expansão dos ideais cristãos", o que projeta o papel específico do éthos do enunciador, orientado por meio de um tom de voz próprio à cena enunciativa pressuposta.

Lucas, figurativização do narrador instaurado no enunciado, escreve o relato não apenas como um simples historiador, mas como um líder pastoral, ao estabelecer uma norma à práxis de uma determinada comunidade de fé. Ele procura, além de fornecer o saber necessário à aquisição do histórico das origens do cristianismo, persuadir o leitor para a edificação e consolidação da fé.

Desse modo, a finalidade do enunciado fundador bíblico, ao apresentar a expansão da mensagem salvífica do cristianismo, mais do que dar sequência ao relato da história de Jesus, faz com que possamos caracterizá-lo como o primeiro relato de divulgação dos ideais cristãos. Observamos, assim, o éthos de um intelectual cristão, de um teólogo que pretende defender, construindo e não apenas transmitindo, as bases de uma doutrina universal.

\section{Considerações finais}


Tomamos a Sagrada Escritura como objeto de estudo a fim de que pudéssemos desvendar o processo de significação do discurso bíblico. Realizamos a análise semiótica de excertos extraídos do Antigo e do Novo Testamento. Procuramos demonstrar como o próprio entendimento da cena fundadora bíblica torna possível depreender o modo de ser e de habitar o espaço social do enunciador responsável por esse discurso. Caracterizamos a Bíblia como discurso fundador de nossa cultura, relato das ações divinas na história, texto fundador de uma religião ou religiosidades, norma a ser seguida pela práxis de uma determinada comunidade de fé. O texto bíblico, considerado como texto de referência primeiro e como discurso fundador dos discursos de fidelização e de divulgação religiosa, devido ao efeito de atemporalidade do discurso religioso, é a base para a discursivização do discurso de divulgação religiosa.

Os resultados de nossa análise se refletem na incorporação de um sujeito modalizado pela paixão fiduciária da crença que, dado o caráter intersubjetivo proposto, institui a relação entre o sujeito e o exercício da própria fé. A esse sujeito, que deixa transparecer partes de seu corpo, na percepção de um mundo discursivizado, propomos associar, com apoio em Discini (2004), a noção de aspectualização do ator da enunciação, à noção de estilo (éthos), o que projeta o papel específico do éthos do enunciador, orientado por meio de um tom de voz próprio à cena enunciativa pressuposta.

\section{Referências}

BÍBLIA SAGRADA. Tradução da CNBB. 6a. ed. Trad. Conferência Nacional dos Bispos do Brasil. São Paulo: Edições CNBB, 2007.

BRUNEL, P. Dicionário de Mitos Literários. Rio de Janeiro: José Olympio, 1997.

CARDOSO, Dario de Araújo. A emergência do sentido nas narrativas bíblicas: uma proposta de pesquisa semiótica na Bíblia. Cadernos de Pós-Graduação em Letras (online), v. 15, p. 1-19, 2015.

. Corpo e presença na Bíblia Sagrada. Tese (Doutorado em Semiótica e Linguística Geral) - Faculdade de Filosofia, Letras e Ciências Humanas, Universidade de São Paulo, São Paulo, 2017. 
CARVALHO, Paulo César de. Fragmentos epistolares de um discurso amoroso: elementos para uma análise semiótica do estatuto do gênero Carta de Amor. Dissertação de Mestrado. São Paulo: Universidade de São Paulo, 2005.

CHABROL, C. Problemas da semiologia narrativa dos textos bíblicos. In: CHABROL, C.; MARIN, L. Semiótica narrativa dos textos bíblicos. Rio de Janeiro: Forense Universitária, 1980, p. 2-12.

DEMARCHI, Guilherme. Da paixão à ressurreição: uma análise semiótica. Tese (Doutorado em Semiótica e Linguística Geral) - Faculdade de Filosofia, Letras e Ciências Humanas, Universidade de São Paulo, São Paulo, 2015.

DISCINI, Norma. O estilo nos textos. São Paulo: Contexto, 2004.

FIORIN, José Luiz. As astúcias da enunciação. São Paulo: Ática, 2002.

FOUCAULT, Michel. O que é um autor? 3ª ed. Lisboa: Passagens, 1997.

GREIMAS, Algirdas Julien. Du Sens. Paris: Seuil, 1970.

. De la colère. In : GREIMAS, Algirdas Julien. Du Sens II : Essais Sémiotiques. Paris : Éditions Du Seuil, 1983a.

. Folclore, religião e história. Trad. Ana Maria Petraitis Liblik. Significação: revista brasileira de estudos semióticos, São Paulo, n. 21, p. 9-28, junho, 2004 (Original Lituano). JADON, José Carlos. Sucesso e salvação - estudo semiótico comparativo entre os discursos televisivos das Igrejas Universal do Reino de Deus e Católica Apostólica Romana no Brasil. Tese (Doutorado em Semiótica e Linguística Geral) - Faculdade de Filosofia, Letras e Ciências Humanas, Universidade de São Paulo, São Paulo, 2009.

JOÃO PAULO II, Papa. Evangelium Vitae: Carta Encíclica de João Paulo II sobre o valor

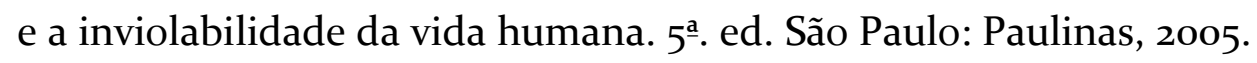

KURTZ, William. Atos dos Apóstolos. In: BERGANT, Diane; KARRIS, Robert (orgs.). Comentário Bíblico. Vol. III. São Paulo, Loyola, 1999, p.143-174.

LIMA, Anderson de Oliveira. A semiótica a serviço da leitura bíblica: Análise da narrativa de Mateus 19.16-24. Darandina Revisteletrônica - Programa de Pós-Graduação em Letras/ UFJF, vol. 6, n.2, 2013. Disponível em: <http://www.ufff.br/darandina/files/2014/o3/artigo_anderson_lima.pdf>. Acesso em: 29 jun. 2019.

MARGUERAT, Daniel. A primeira história do cristianismo: os Atos dos Apóstolos. São Paulo: Loyla, 2003. 
MENDES, Mariza B. T. No princípio era o poder: uma análise semiótica das paixões no discurso do antigo testamento. São Paulo: Annablume, 2009.

PANIER, L. O discurso de interpretação do comentário bíblico. In: GREIMAS, A,J. Análise do Discurso em Ciências Sociais. São Paulo: Global, 1986.

- Une lecture semiotique des textes: questions de theologie biblique. In: Semiotique et Bible, Lyon, Centre pour l'analyse du discours religieux, n. 56, déc. 1989, p. 19-36.

. Sémiotique et etudes bibliques. Évolutions méthodologiques et perpectives épistemologiques. EC - Rivista dell'Associazone Italiana Studi Semiotici, 28 febbr. 2008. Disponível em:<http://www.ec-aiss.it/index_d.php?recordID=71>. Acesso em: 30 jun. 2018.

PERELMAN, Chaïm; OLBRECHTS-TYTECA, Lucie. Tratado de argumentação: A nova retórica. São Paulo: Martins Fontes, 2005.

PIETROFORTE, Antonio Vicente Seraphin Pietroforte. O discurso da Tradição esotérico Religiosa: uma abordagem semiótica. Dissertação (Mestrado em Semiótica e Linguística Geral) - Faculdade de Filosofia, Letras e Ciências Humanas, Universidade de São Paulo, São Paulo, 1997.

POSTAL, Jairo. Uma imagem caleidoscópica de Jesus: o éthos de Cristo depreendido dos evangelhos canônicos. Tese (Doutorado em Letras) - Universidade Presbiteriana Mackenzie, São Paulo, 2010.

THÉRIAULT, J-Y. Quand la bible s'ouvre à la lecture sémiotique. Proteé: revue internationale de théories et de pratiques sémiotiques, v. 34, n. 1, p. 67-75, 2006.

ZILBERBERG, Claude. Elementos de Semiótica Tensiva. São Paulo: Ateliê editorial, 2011.

\footnotetext{
* Professora da Universidade Federal do Mato Grosso do Sul e Doutora em Semiótica e Linguística Geral pela Universidade de São Paulo.
} 